\title{
Analysis of a Goods Wagon Running on a Railway Test Track
}

Ján Dižo

Faculty of Mechanical Engineering, University of Žilina. Univerzitná 8215/1, 01026 Žilina. Slovak republic. E-mail: jan.dizo@fstroj.uniza.sk

An intermodal transport is nowadays an inseperable part of a transport system. Designs of longer wagons are the result of efforts to achieve universality, transport capacity increase, reducing of noise and maintenance needs. In this paper are presented results of selected parametres of a long goods wagon driving on a test track. The long goods wagon and test rings models have been created by using the ADAMS/Rail software. The analysed wagon has been equipped by the Y25 bogie. Simulations of the long goods wagon running have been performed on the model of railway test rings - VÚŽ Velim, Cerhenice. For the dynamic analysis of the long goods wagon have been selected two sections of the railway test rings. For the ride properties wagon assessemnt have been selected output signals of vertical forces $Q$, guiding forces $Y$ and the $Y / Q$ ratio. There have been detected, values of assessed parametes have not been exceeded the limited values and therefore wagon runnings have been safety.

Keywords: Goods wagon, Y25 bogie, Railway test track, Ride properties

\section{Acknowledgement}

This paper was created during the processing of the project "RAILBCOT - RAIL Vehicles Brake Components Test Stand", ITMS Code 26220220011 based on the support of Research and Development Operational Program financed by European Fund of a Regional Development.

\section{References}

[1] BLATNICKÝ, M. (2015). Checks Crane Hooks. In: Manufacturing Technology. Vol. 15, No 5 (2015). ISSN 12132489. Pp. 766-771.

[2] BOSSO, N., GUGLIOTTA, A., SOMÁ, A. (2000). Simulation of a freight bogie with friction dampers. 5th ADAMS/Rail User's Conference Haarlem, The Netherlands - May 10th - 11th, 2000.

[3] CHALUPA, M. (2015). The Using of Vehicle Moving Simulation to Proposal of Construction Work. In: Manufacturing Technology. Vol. 15, No 5 (2015). ISSN 1213-2489. Pp. 845-850.

[4] DIŽO, J., GERLICI, J., LACK, T. (2013). The goods wagon equipped by Y25 bogies computer simulation analysis. In: TRANSCOM 2013, section 6, EDIS - Žilina University Publisher. ISBN 978-80-554-0695-4. Pp. 63 - 66.

[5] FABIÁN, P., GERLICI, J., MAŠEK, J., MÁRTON, P. (2013). Versatile, efficient and long wagon for intermodal transport in Europe. In: Communications: scientific letters of the University of Žilina. - Vol. 15, No. 2. ISSN 13354205. Pp. 118-123.

[6] GERLICI, J., LACK, T., HARUŠINEC, J. (2014). Realistic simulation of railway operation on the RAILBCOT test stand. In: Applied mechanics and material. Vol. 486. ISSN 1660-9336. Pp. 387-395.

[7] JAKUBOVIČOVÁ, L., SÁGA, M., VAŠKO, M. (2013). Impact Analysis of Mutual Rotation of Roller Bearing Rings on the Process of Contact Stresses in Rolling Elements. In: Manufacturing Technology. Vol. 13, No 1 (2013). ISSN 1213-2489. Pp. 50-54.

[8] LACK, T., GERLICI, J. (2014). Modified strip method specification for wheel/rail contact stress evaluation. In: Prace Naukowe. Transport: Analiza I ocean elementów systemów transportowych. Z. 101. ISSN 1230-9265. Pp. 63-82.

Online: http://www.wt.pw.edu.pl/var/ezflow_site/storage/original/application/83bbe4bc0bf7c4c4b704e53b9637c3a6.pdf.

[9] LACK, T., GERLICI, J. (2014). A modified strip method to speed up the calculation of normal stress between wheel and rail. In: Applied mechanics and material. Vol. 486 (2014). ISSN 1660-9336. Pp. 359-370.

[10] POLÁCH, P. (2015). Influence of the Shock Absorbers Type Change at Stress of the Troleybus Chassis. In: Manufacturing Technology. Vol. 15, No 1 (2015). ISSN 1213-2489. Pp. 77-86.

[11] SKOČILASOVÁ, B., SKOČILAS, J., SOUKUP, J. (2008). Experimental determination of natural frequencies and stiffness of suspension of flexible mounted body, aplication on road and railway vehicles (In Czech). Acta Mechanica Slovaca, No. 3-B/2008, CD ROM, vol. 12, Košice, 2008. ISSN 1335-2393. Pp. 715 - 726. 
[12] SUCHÁNEK, A., HARUŠINEC, J. (2015). The Downhill Braked Railway Wheel Structural Analysis by Means of the ANSYS Multiphysics Program System Package. In: Manufacturing Technology. Vol. 15, No 5 (2015). ISSN 1213-2489. Pp. 945-950.

[13] SVOBODA, M., SKOČILASOVÁ, B. (2010). Analytical analysis of vertical vibration of mechanical system of bodies. Presentation of Proceedings of Extended Abstracts of 26th Conference with International Participation Computational Mechanics 2010, University of West Bohemia in Plzeň, Hrad Nečtiny, November 2010.

[14] SVOBODA, M., SOUKUP, J. (2013). Verification of Numeric Solution by Experiment for Examination Vertical Oscillation of a Mechanical System. In: Manufacturing Technology. Vol. 13, No 4 (2013). ISSN 1213-2489. Pp. 559-563.

[15] ŠŤASTNIAK, P., HARUŠINEC, J. (2013). Computer aided simulation analysis for computation of modal analysis of the fright wagon. In: Communications: scientific letters of the Universtity of Žilina, Vol. 15, April 2013. ISSN 1335 - 4205. Pp. $73-79$.

[16] ADAMS/Rail, User manual, 2005: MSC.Software\MSC.ADAMS 2005 r2

[17] Railway Research Institute, j.s.c.: http://www.cdvuz.cz/zkusebni-centrum-vuz-velim/

Copyright (C) 2016. Published by Manufacturing Technology. All rights reserved. 